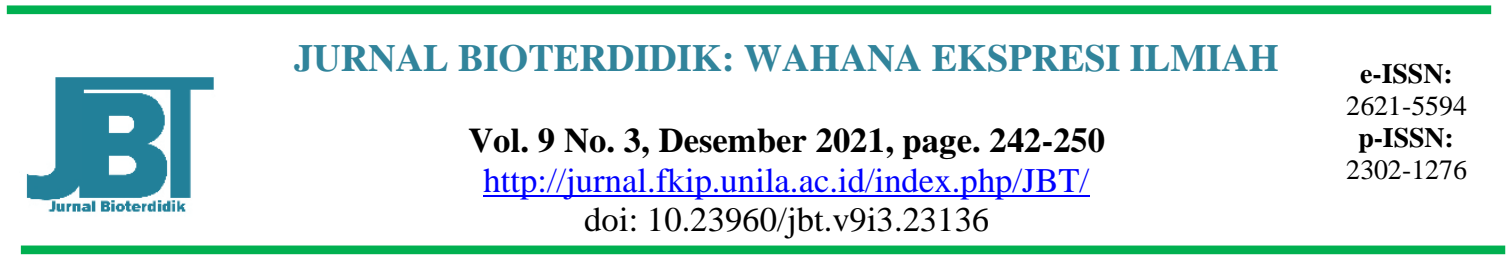

\title{
Pengaruh Model Pembelajaran Probing Promting Terhadap Kemampuan Berpikir Kritis Dan Hasil Belajar Biologi Siswa Kelas XI Mas Cipta
}

\author{
Nurliana*, Indayana Febriani Tanjung, Khairuddin \\ Tadris Biologi, Fakultas Ilmu Tarbiyah dan Keguruan, Universitas Islam Negeri Sumatera Utara \\ *e-mail: nurlianaira96@gmail.com
}

Received: November 20, 2021

Accepted: December 24, 2021

Online Published: December 30, 2021

\begin{abstract}
The Influence of Probing Prompting Learning Model on Critical Thinking and Biology Learning Outcomes of Class XI Mas Cipta. This study aims to determine the effect of the probing learning model on critical thinking skills and biology learning outcomes for class XI students. This type of research is quasi-experimental research. The sample of this research is class XI IPA 2 opens 30 people as experimental class and XI IPA 3 opens 30 people as control class. The instrument used to collect data is a multiple-choice test consisting of 20 critical thinking skills questions and 20 learning outcomes test questions. Data analysis in this study was a paired simple t test with the help of the SPSS 20.00 program. The results of the analysis of critical thinking skills obtained tcount $=$ 24,418 and ttable = 2,045, which means Ho is rejected, Ha is accepted. This shows that there is an effect of the probing learning model on the critical thinking skills of class XI MAS Cipta Simpang Dolok T.P 2019/2020 students. Meanwhile, from the results of the analysis of the results obtained tcount $=22,381$ and ttable $=2.405$, which means that Ho is rejected, Ha is accepted. This shows that there is an effect of the probing prompting learning model on the learning outcomes of class XI Mas Cipta.
\end{abstract}

Keywords: Probing Prompting Model, Critical Thinking Ability and Learning Outcomes

\begin{abstract}
Abstrak: Pengaruh Model Pembelajaran Probing Prompting Terhadap Pemikiran Berpikir Kritis Dan Hasil Belajar Biologi Siswa Kelas XI Mas Cipta. Penelitian ini bertujuan untuk mengetahui pengaruh model pembelajaran probing promting terhadap kemampuan berpikir kritis dan hasil belajar biologi siswa kelas XI. Jenis penelitian ini merupakan penelitian kuasi eksperimen. Sampel penelitian ini adalah kelas XI IPA 2 berjumlah 30 orang sebagai kelas eksperimen dan XI IPA 3 berjumlah 30 orang sebagai kelas kontrol. Instrumen yang digunakan untuk mengumpulkan data adalah tes berbentuk pilihan ganda yang terdiri dari 20 soal kemampuan berpikir kritis dan 20 soal tes hasil belajar. Analisis data pada penelitian ini adalah uji paired simple t test dengan bantuan program SPSS 20.00. Dari hasil analisis kemampuan berpikir kritis siswa diperoleh $\mathrm{t}_{\text {hitung }}=24,418$ dan $\mathrm{t}_{\text {tabel }}=2,045$ yang artinya Ho ditolak Ha diterima. Hal ini menunjukkan ada pengaruh model pembelajaran probing promting terhadap kemampuan berpikir kritis siswa kelas XI MAS Cipta Simpang Dolok T.P 2019/2020. Hasil analisis hasil belajar diperoleh $\mathrm{t}_{\text {hitung }}=22,381$ dan $\mathrm{t}_{\text {tabel }}=2,405$ yang artinya artinya Ho ditolak Ha diterima. Hal ini menunjukkan ada pengaruh model pembelajaran probing promting terhadap hasil belajar siswa kelas XI MAS Cipta Simpang Dolok T.P 2019/2020.
\end{abstract}

Kata kunci: hasil belajar, kemampuan berpikir kritis, model probing promting 


\section{PENDAHULUAN}

Pendidikan merupakan sebuah proses kegiatan yang disengaja atas input siswa untuk menimbulkan suatu hasil yang diinginkan sesuai tujuan yang ditetapkan. Sebagai sebuah proses sengaja maka pendidikan harus di evaluasi hasilnya untuk melihat apakah hasil yang dicapai telah sesuai dengan tujuan yang diinginkan dan apakah proses yang dilakukan efektif untuk mencapai hasil yang diinginkan (Purwanto, 2014). Pendidikan di sekolah mempunyai tujuan untuk mengubah agar dapat memiliki pengetahuan keterampilan dan sikap pelajar sebagai bentuk perubahan hasil belajar. Mewujudkan suatu perubahan dalam kehidupan seseorang siswa dapat dibuktikan dari hasil belajar siswa terhadap materi yang dipelajari yang dibuktikan oleh nilai. Perubahan itu diupayakan dalam proses belajar mengajar untuk mencapai tujuan pendidikan.

Agama Islam sangat menganjurkan untuk senantiasa belajar dan terus belajar bahkan diwajibkan. Karena dengan belajar akan mendapatkan ilmu yang dapat digunakan untuk memecahkan masalah kehidupan. Begitu sebaliknya orang yang tidak belajar tidak akan mendapatkan ilmu pengetahuan. Sebagaimana firman Allah SWT dalam Surah Al-Isra ayat 36:

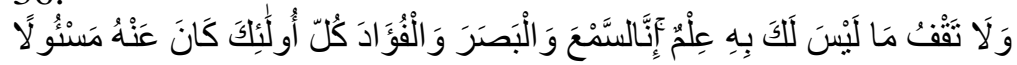

Artinya : Dan janganlah kamu mengikuti apa yang kamu tidak mempunyai pengetahuan tentangnya. Sesungguhnya pendengaran, penglihatan dan hati, semuanya itu akan diminta pertanggungan jawabnya. (Q.S. Al-Isra:36).

Dari ayat di atas, bahwasanya Allah memerintahkan umat islam untuk terus belajar, agar mempunyai ilmu pengetahuan, agar tidak mengikuti perkataan atau perbuatan yang tidak diketahui ilmunya, karena banyak kerusakan yang disebabkan oleh perkataan dan perbuatan tanpa didasari ilmu pengetahuan.

Menurut Sardiman dalam Istirani, belajar adalah usaha merubah tingkah laku. Belajar dapat diartikan secara sederhana yakni, sebuah proses yang dengannya organisme memperoleh bentuk-bentuk perubahan perilaku yang cenderung terus mempengaruhi model perilaku umum menuju pada peningkatan. Sementara itu menurut Wina Sanjaya, pembelajaran merupakan proses belajar yang diarahkan pada usaha menciptakan lingkungan belajar yang dapat mendorong terhadap pengembangan kognitif, serta untuk pembentukan keterampilan mental tertentu seperti keterampilan berpikir kritis, berpikir kreatif dan lain sebagainya.

Menurut Sardiman dalam Istirani, belajar adalah usaha merubah tingkah laku. Belajar dapat diartikan secara sederhana yakni, sebuah proses yang dengannya organisme memperoleh bentuk-bentuk perubahan perilaku yang cenderung terus mempengaruhi model perilaku umum menuju pada peningkatan. Sementara itu menurut Wina Sanjaya, pembelajaran merupakan proses belajar yang diarahkan pada usaha menciptakan lingkungan belajar yang dapat mendorong terhadap pengembangan kognitif, serta untuk pembentukan keterampilan mental tertentu seperti keterampilan berpikir kritis, berpikir kreatif dan lain sebagainya.

Berdasarkan hasil wawancara dengan guru biologi di Madrasah Aliyah Swasta Cipta Simpang Dolok diperoleh data bahwa nilai KKM mata pelajaran biologi di sekolah tersebut adalah 82 dan nilai yang didapatkan siswa masih banyak yang tidak mencapai KKM. Siswa yang mendapatkan nilai di bawah KKM sebanyak 56\% dari jumlah siswa dengan rata-rata nilai siswa 70. Hal ini menunjukan hasil belajar biologi di sekolah ini rendah. 
Guru sebagai pengajar perlu mengatasi hal tersebut salah satunya dengan menerapkan model pembelajaran yang lebih menarik bagi siswa sehingga siswa dapat memiliki kemampuan berpikir kritis dan memiliki hasil belajar yang baik. Salah satu model pembelajaran yang dapat meningkatkan hasil belajar dan kemampuan berpikir kritis siswa yaitu model pembelajaran probing prompting. Probing prompting adalah suatu model pembelajaran yang berpusat pada siswa, karena siswa diberi keluasan untuk aktif dalam membangun pengetahuannya sendiri, mendorong siswa untuk berpikir dan memberikan kesempatan kepada siswa menanyakan hal-hal yang kurang jelas, dan mengembangkan keberanian siswa dalam menjawab dan mengemukakan pendapat.

Berdasarkan latar belakang diatas, maka rumusan masalah dalam penelitian ini adalah:

1. Apakah terdapat pengaruh model pembelajaran probing promting terhadap kemampuan berfikir kritis siswa pada materi sistem pernapasan pada manusia di kelas XI MAS Cipta Simpang Dolok?

2. Apakah terdapat pengaruh model pembelajaran probing promting terhadap hasil belajar siswa pada materi sistem pernapasan pada manusia di kelas XI MAS Cipta Simpang Dolok?

Adapun tujuan dari penelitian ini adalah untuk mengetahui:

1. Pengaruh model pembelajaran probing promting terhadap kemampuan berfikir kritis siswa pada materi sistem pernapasan pada manusia di kelas XI MAS Cipta Simpang Dolok.

2. Pengaruh model pembelajaran probing promting terhadap hasil belajar siswa pada materi sistem pernapasan pada manusia di kelas XI MAS Cipta Simpang Dolok.

\section{METODE}

Metode penelitian ini menggunakan penelitian eksperimen semu atau disebut "Quasy experiment". Quasy experiment ini digunakan untuk mengetahui hubungan sebab akibat dengan cara melibatkan kelompok kontrol disamping kelompok eksperimen, yang bertujuan untuk mengetahui ada tidaknya pengaruh dari perlakuan yang diberikan terhadap subjek yang diteliti dengan menggunakan model pembelajaran kooperatif Probing Promting pada materi sistem pernapasan manusia pada kelompok eksperiman dan model pembelajaran konvensional (ceramah) pada kelompok kontrol.

\section{HASIL DAN PEMBAHASAN}

Berdasarkan Tabel 1 diketahui bahwa nilai rata - rata pre-test kelas eksperimen adalah 33,33, termasuk kategori kemampuan berpikir kritis rendah dan kelas kontrol adalah 16,33 termasuk kategori kemampuan berpikir kritis rendah. Nilai rata -rata post-test kelas eksperimen adalah 83,33 termasuk kategori berpikir kritis sangat tinggi dan kelas kontrol adalah 67,33 dan termasuk kategori kemampuan berpikir kritis tinggi. Pada hasil posttest standar deviasi dan variansi kelas kontrol lebih tinggi daripada kelas eksperimen, artinya tingkat keragaman pada kelompok kontrol lebih besar. Median atau nilai tengah pada kelas eksperimen juga lebih tinggi dibandingkan kelas kontrol. 
Tabel 1. Deskriptif Statistik

\begin{tabular}{lcccccc}
\hline \multicolumn{6}{c}{ Descriptive Statistics } \\
\hline $\begin{array}{l}\text { Kemampuan } \\
\text { Berpikir Kritis }\end{array}$ & N & Min & Max & Mean & $\begin{array}{c}\text { Std. } \\
\text { Deviation }\end{array}$ & Variance \\
\hline $\begin{array}{l}\text { Pretest } \\
\text { Eksperimen }\end{array}$ & 30 & 20 & 60 & 33,33 & 9,767 & 95,402 \\
\hline $\begin{array}{l}\text { PostTest } \\
\text { Eksperimen }\end{array}$ & 30 & 80 & 90 & 83,33 & 3,032 & 9,195 \\
\hline $\begin{array}{l}\text { Pretest Kontrol } \\
\text { PostTest }\end{array}$ & 30 & 5 & 30 & 16,33 & 9,185 & 84,368 \\
\begin{tabular}{l} 
Kontrol \\
\hline
\end{tabular} & 30 & 55 & 85 & 67,33 & 7,739 & 59,885 \\
\hline
\end{tabular}

Berdasarkan data yang disajikan pada Tabel 1 dapat dibuat histogram perbandingan rata - rata nilai pre-test dan post-test kemampuan berpikir kritis eksperimen dan kontrol seperti pada Gambar 1. Berdasarkan Gambar 1.1 dapat diketahui bahwa kelas eksperimen dengan pembelajaran probing promting dan kelas kontrol dengan pembelajaran konvensioanl mengalami peningkatan dari nilai pre-test ke nilai post-test. Peningkatan kemampuan berpikir kritis kelas dengan model pembelajaran probing promting lebih tinggi dibandingkan dengan konvensional.

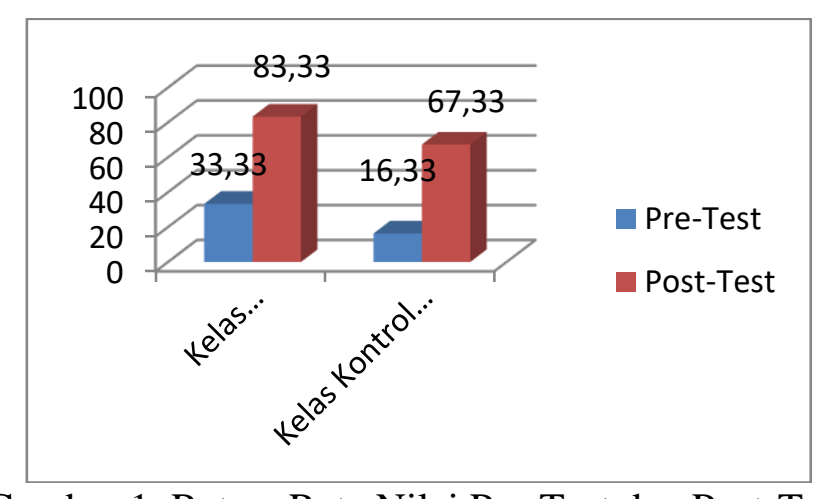

Gambar 1. Rata - Rata Nilai Pre-Test dan Post-Test

Perbandingan nilai rata-rata kemampuan berpikir kritis siswa pada kelas kontrol dengan pembelajaran konvensional dan kelas eksperimen dengan pembelajaran probing promting untuk setiap indikatornya secara lengkap dapat dilihat pada Tabel 2.

Diagram batang perbandingan rata-rata post-test aspek kemampuan berpikir kritis kelas eksperimen dan kelas kontrol seperti ditunjukkan pada Gambar 2. Berdasarkan Gambar 2 diketahui bahwa setiap indikator berpikir kritis pada kelas eksperimen dengan pembelajaran probing promting lebih tinggi dibandingkan kelas kontrol dengan pembelajaran konvensional. 1). Memberikan penjelasan dasar, kelas eksperimen dengan nilai 88,6 termasuk kategori berpikir kritis tinggi sekali dan kelas kontrol dengan nilai 72 termasuk kategori berpikir kritis tinggi. 2) Membangun keterampilan dasar, kelas eksperimen dengan nilai 82 termasuk kategori berpikir kritis tinggi sekali dan kelas kontrol dengan nilai 70 termasuk kategori berpikir kritis tinggi. 3) Penarikan kesimpulan, kelas eksperimen dengan 
nilai 83,3 termasuk kategori berpikir kritis tinggi sekali dan kelaskontrol dengan nilai 68,3 termasuk kategori berpikir kritis tinggi. 4) Membuat penjelasan lebih lanjut, kelas eksperimen dengan nilai 85,5 termasuk kategori berpikir kritis tinggi sekali dan kelas kontrol dengan nilai 68,6 termasuk kategori berpikir kritis tinggi. 5) Strategi dan taktik, kelas eksperimen dengan nilai 81 termasuk kategori berpikir kritis tinggi sekali dan kelas kontrol dengan nilai 66,6 termasuk kategori berpikir kritis tinggi.

Tabel 2. Nilai Rata-Rata Setiap Indikator

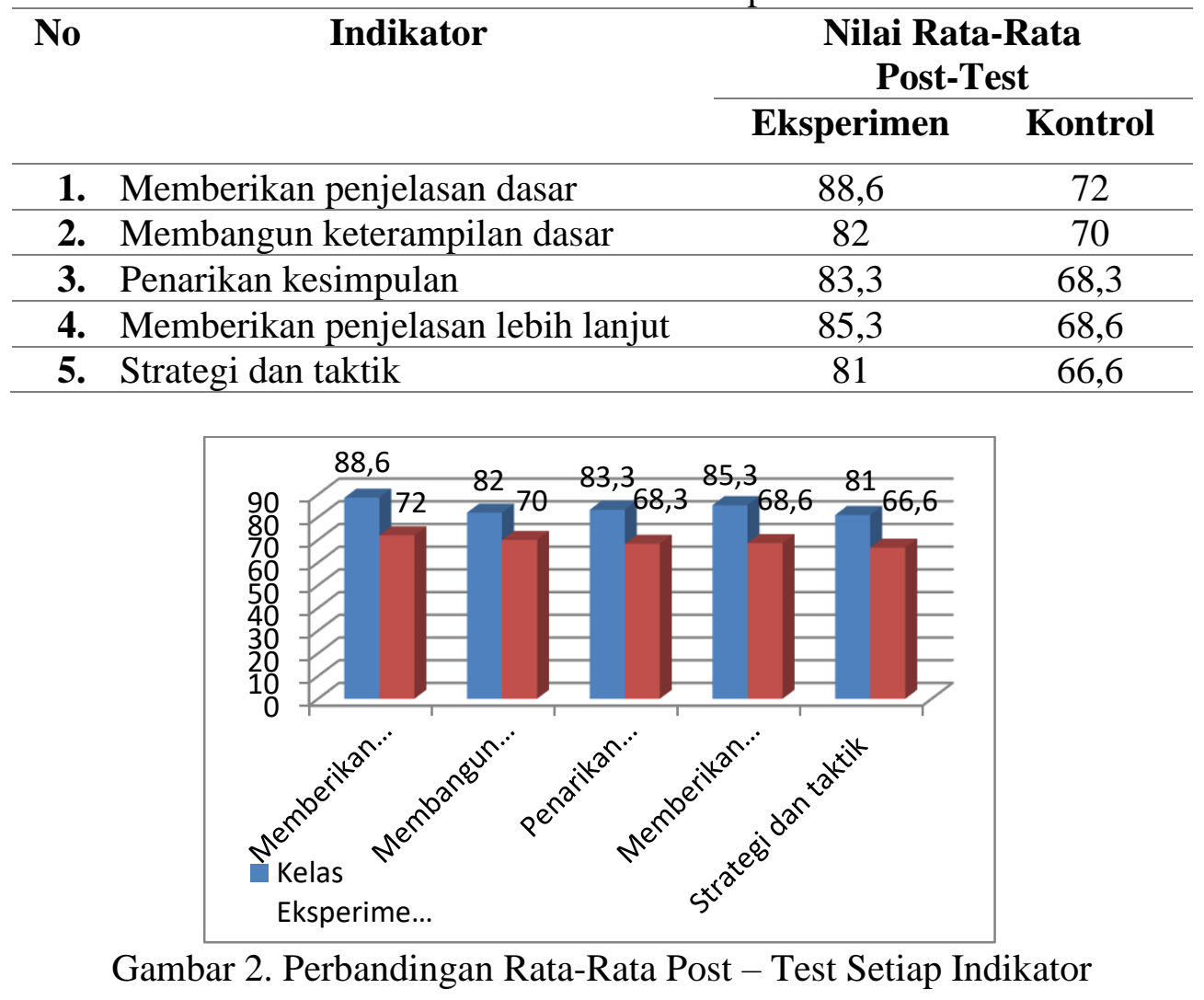

Berdasarkan hasil penelitian dapat dibuat histogram perbandingan rata - rata nilai pretest dan post-test hasil belajar kelas eksperimen dan kelas kontrol seperti pada Gambar 3. Berdasarkan Gambar 3 dapat diketahui bahwa kelas eksperimen dengan pembelajaran probing promting dan kelas kontrol dengan pembelajaran konvensioanl mengalami peningkatan dari nilai pre-test ke nilai post-test. Peningkatan hasil belajar kelas dengan model pembelajaran probing promting lebih tinggi dibandingkan dengan model pembelajaran konvensional.

Perbandingan nilai rata-rata hasil belajar siswa pada kelas kontroldengan pembelajaran konvensional dan kelas eksperimen dengan pembelajaran probing promtinguntuk setiap indikatornya secara lengkap dapat dilihat pada Tabel 3. 


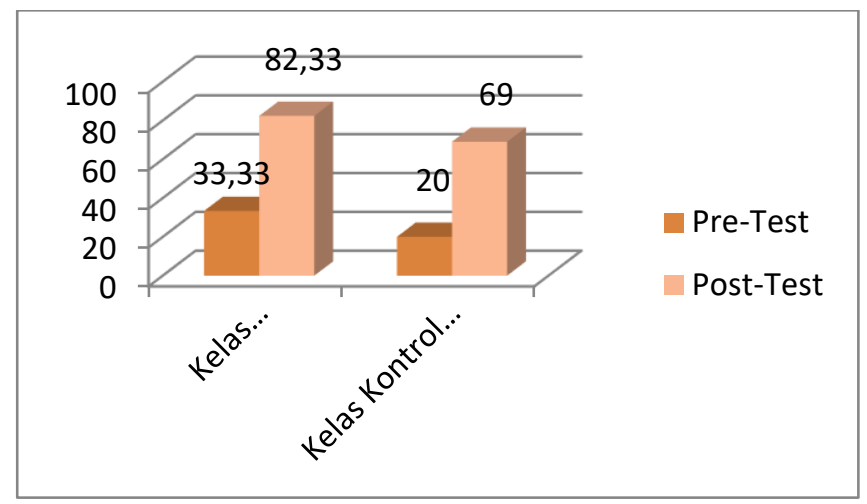

Gambar 3. Rata - Rata Nilai Pre-Test dan Post Test

Tabel 3. Nilai Rata-Rata Hasil Belajar Siswa Setiap Indikator

\begin{tabular}{llcc} 
No & \multicolumn{1}{c}{ Indikator } & \multicolumn{2}{c}{ Nilai Rata-Rata Post-Test } \\
\cline { 3 - 4 } & & Eksperimen & Kontrol \\
& & & \\
\hline 1. & C1 (Mengingat) & 95 & 90 \\
\hline 2. & C2 (Memahami) & 82,5 & 73,7 \\
\hline 3. & C3 (Menerapkan) & 84 & 73,3 \\
\hline 4. & C4 (Menganalisis) & 65,5 & 60 \\
\hline 5. & C5 (Mengevaluasi) & 86,6 & 58,3 \\
\hline
\end{tabular}

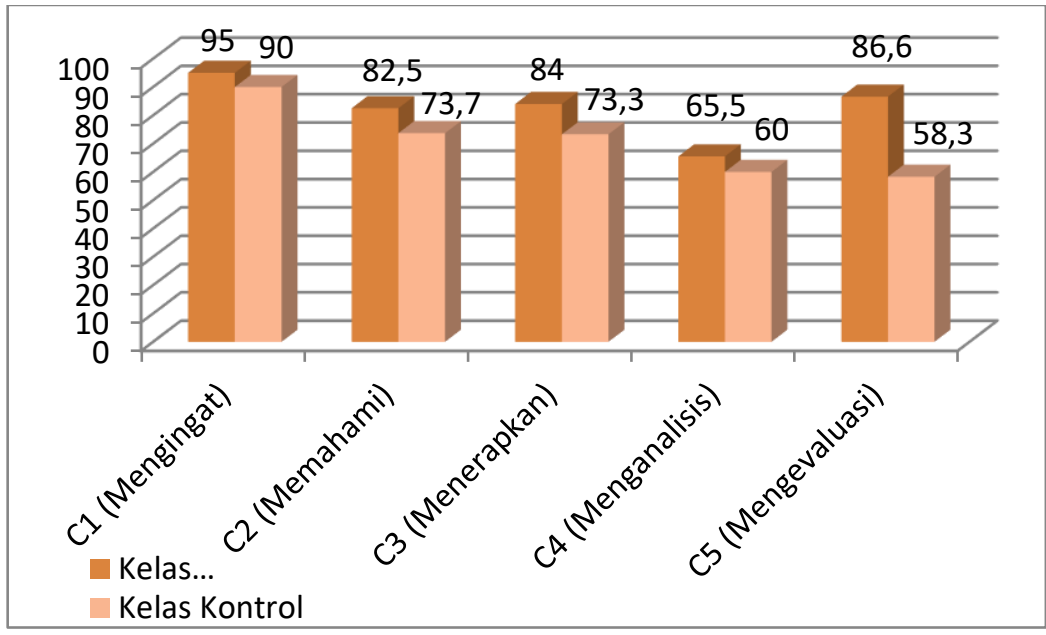

Gambar 4. Perbandingan Rata-Rata Pot-Test Setiap Indikator

Diagram batang perbandingan rata-rata post-test aspek kemampuan berpikir kritis kelas eksperimen dan kelas kontrol seperti ditunjukkan pada Gambar 4. Berdasarkan Gambar 4 diketahui bahwa setiap indikatorhasil belajar pada kelas eksperimen dengan pembelajaran probing promting lebih tinggi dibandingkan kelas kontrol dengan pembelajaran konvensional. 1). C1 (Mengingat), kelas eksperimen dengan nilai 95 termasuk kategori hasil belajar sangat tinggi dan kelas kontrol dengan nilai 90 termasuk kategori hasil belajar sangat tinggi. 2) C2 (Memahami), kelas eksperimen dengan nilai 82,5 termasuk kategori hasil 
belajar tinggi dan kelas kontrol dengan nilai 73,7 termasuk kategori hasil belajar sedang. 3) C3 (Menerapkan), kelas eksperimen dengan nilai 84termasuk kategori hasil belajar tinggi dan kelas kontrol dengan nilai 73,3 termasuk kategori hasil belajar sedang. 4) C4 (Menganalisis), kelas eksperimen dengan nilai 65,5 termasuk kategori hasil belajar rendah dan kelas kontrol dengan nilai 60 termasuk kategori hasil belajar rendah. 5) C5 (Mengevaluasi), kelas eksperimen dengan nilai 86,6 termasuk kategori hasil belajar tinggidan kelas kontrol dengan nilai 58,3 termasuk kategori hasil belajar rendah.

Kemampuan Berpikir Kritis. Berdasarkan hasil uji hipotesis dengan menggunakan uji t-paired simple test dengan bantuan program SPSS 20,0, dapat diketahui bahwa kemampuan berpikir kritis siswa pada sistem pernapasan dengan menggunakan model pembelajaran probing promting menghasilkan kemampuan berpikir kritis lebih tinggi dibandingkan dengan menggunakan model pembelajaran konvensional. Hal ini sesuai dengan teori Suherman dalam Tri Utari bahwa pembelajaran Probing Promting dapat meningkatkan proses berpikir yang mampu mengaitkan pengetahuan dan pengalaman siswa dengan pengetahuan baru yang sedang dipelajari. Karena pada langkah model pembelajaran ini terdapatguru mengajukan persoalan yang sesuai dengan indikator kepada seluruh siswa dan menunjuk salah satu siswa untuk menjawab pertanyaan. Dari langkah ini, siswa dapat meningkatkan kemampuan berpikir untuk menjawab pertanyaan yang di ajukan oleh guru.

Hasil penelitian ini mendukung penelitian sebelumnya oleh Helma Mustika dkk., tahun 2017 bahwa nilai rata-rata kelas eksperimen lebih tinggi daripada kelas kontrol, dengan nilai rata-rata kelas eksperimen 85,87 dan nilai rata-rata kelas kontrol 80. Dari analisis uji hipotesis diperoleh $\mathrm{t}_{\text {hitung }}=2,081$ dan $\mathrm{t}_{\text {tabel }}=1,997$. Hasil tes pemecahan masalah matematika yang menggunakan model pembelajaran probing promting lebih baik daripada hasil tes kemampuan pemecahan masalah matematika siswa dengan menggunakan model pembelajaran konvensioanl (Mustika, 2017). Sejalan dengan hasil penelitian Elsa Susanti pada tahun 2017 yaitu terdapat penigkatan kemampuan berpikir kritis matematis siswa kelas XI IPA MAN 1 Kota Bengkulu dengan menerapkan model pembelajran Probing Promting (Susanti, 2017). Dengan demikian dapat disimpulkan bahwa penggunaan model pembelajaran probing promting dapat meningkatkan kemampuan berpikir kritis siswa dalam pembelajaran.

Model pembelajaran probing promting adalah model pembelajaran yang berpusat pada siswa. Model pembelajaran ini dapat membantu siswa untuk menggali pengetahuan dalam diskusi kelompok. Selain itu guru juga dituntut untuk membimbing siswa dengan memberikan pertanyaan yang mengarah ke pembahasan (Danaryanti, 2016). Menurut Ngalimun dalam Lukmanul Hakim dkk., pembelajaran probing promting adalah pembelajaran dengan memberikan serangkaian pertanyaan yang sifatnya menuntun dan menggali gagasan siswa sehingga terjadi proses berpikir yang dapat mengaitkan pengetahuan dan pengalaman siswa dengan pengetahuan baru yang sedang dipelajari (Hakim dkk, 2016).

Pada hasil post-test kemampuan berpikir kritis yang telah dilakukan pada kelas eksperimen dan kontrol terdapat berbedaan nilai rata-rata post-test. Pada kelas eksperimen diperoleh rata-rata 83,33 sedangkan pada kelas kontrol diperoleh rata-rata 67,33, artinya ratarata post-test kelas eksperimen dengan model pembelajaran probing promting lebih tinggi dari pada kelas kontrol dengan model pembelajaran konvensional, sehingga dapat dikatakan bahwa model pembelajran probing promtingberpengaruh terhadap kemampuan berpikir 
kritis siswa. Dengan demikian dapat disimpulkan bahwa terdapat pengaruh model pembelajaran probing promting terhadap kemampuan berpikir kritis siswa.

Hasil Belajar Siswa. Dari hasil uji hipotesis dengan menggunakan uji t-paired simple test dengan bantuan program SPSS 20,0, dapat diketahui bahwa hasil belajar siswa pada sistem pernapasan dengan menggunakan model pembelajran probing promting menghasilkan hasil belajar lebih tinggi dibandingkan dengan menggunakan model pembelajaran konvensional. Hal ini sesuai dengan teori hasil belajar Mulyasa yang menyatakan bahwa dari segi hasil, proses pembelajran dikatakan berhasil apabila terjadi perubahan perilaku yang positif pada diri peserta didik seluruhnya atau setidaknya sebagian besar $75 \%$.

Pada penelitian ini mendapatkan hasil sig < 0,05 dengan nilai $0,00<0,05$ dan diperoleh diperoleh $\mathrm{t}_{\text {hitung }}=22,381$ dan $\mathrm{t}_{\text {tabel }}=2,418$, artinya terdapat pengaruh yang signifikan model pembelajaran probing promting terhadap hasil belajar siswa. Hal ini didukung oleh penelitian yang dilakukan oleh Reny, dkk., tahun 2018 dengan hasil yang diperoleh menunjukkan bahwa model pembelajaran probing promting berpengaruh terhadap hasil belajar siswa. Menurut Ni Luh Resi Meilifa Abdi Putri hal ini dapat terjadi karena penerapan model pembelajaran probing prompting dapat membantu siswa dalam mengkontruksi pengetahuannya sendiridengan materi pelajaran yang sedang dipelajari melalu serangkaian pertanyaan yang disampaikan oleh guru (Putra, 2016).

Berdasarkan hasil analisis nilai rata-rata post-test hasil belajar siswa yang telah dilakukan terdapat perbedaan antara kelas eksperimen dan kelan kontrol. Pada kelas eksperimen diperoleh nilai rata-rata 82,33, dan pada kelas kontrol diperoleh nilai rata-rata 69. Artinya rata-rata pot-test kelas ekperimen lebih tinggi dibandingkan dengan kelas kontrol. Sehingga dapat dikatakan bahwa model pembelajaran probing promting berpengaruh terhadap hasil belajar siswa.

Hasil penelitian ini didukung oleh penelitian yang dilakukan oleh Safitri tahun 2015 yang menyatakan pembelajaran probing prompting dapat meningkatkan prestasi dan hasil belajar. Berdasarkan dari peneliti terdahulu dapat disimpulkan bahwa model pembelajaran dapat mempengaruhi hasil belajar siswa (Safitri, 2015). Hal ini sejalan dengan penelitian yang dilakukan oleh Ketut Agus Wartawan, dkk., tahun 2017 berdasarkan deskripsi data hasil penelitian menunjukkan bahwa terdapat perbedaan hasil belajar antara kelompok siswa yang dibelajarkan dengan model pembelajaran probing-prompting dengan kelompok siswa yang tidak dibelajarkan menggunakan model pembelajaran probing prompting (Artawan, 2017). Dengan demikian dapat disimpulkan bahwa terdapat pengaruh model pembelajaran probing promting terhadap hasil belajar siswa.

\section{SIMPULAN}

Berdasarkan hasil analisis data dan pembahasan dapat disimpulkan bahwa terdapat pengaruh model pembelajaran Probing Promting terhadap kemampuan berpikir kritis siswa pada materi sistem pernapasan pada manusia di kelas XI MAS Cipta Simpang Dolok. Dengan nilai sig $<0,05$ dengan nilai $0,00<0,05$ dan diperoleh $t_{\text {hitung }}=24,418$ dan $t_{\text {hitung }}=2,045$. Ada pengaruh model pembelajaran Probing Promting terhadap hasil belajar siswa pada materi sistem pernapasan pada manusia di kelas XI MAS Cipta Simpang Dolok. Dengan nilai sig < 0,05 dengan nilai $0,00<0,05$ dan diperoleh $\mathrm{t}_{\text {hitung }}=22,381$ dan $\mathrm{t}_{\text {tabel }}=2,045$ 


\section{DAFTAR RUJUKAN}

Agus, K, et. al. (2017). Pengaruh Model Pembelajaran Probing Prompting Terhadap Hasil Belajar IPA Pada Siswa Kelas V SD. Journal PGSD Universitas Pendidikan Ganesha Mimbar PGSD, 5(2).

Alquran dan Terjemahan. (2015). Departemen Agama RI. Bandung: CV. Darus Sunah.

Arikunto, S. (2017). Prosedur Penelitian Suatu Pendekatan Praktik. Jakarta: Rineka Cipta. Danaryanti, A. dkk. (2016). Penerapan Model Probing Promting Learning Untuk Meningkatkan Kemampuan Koneksi Matematis Siswa SMP. Jurnal Pendidikan Matematika FKIP Universitas Lambung Mangkura. 4(1).

Hakim, L. dkk., 2016. Penerapan Metode Pembelajaran Probing Promting Untuk Meningkatkan Aktivitas dan Hasil Belajar Siswa Pada Mata Pelajaran Konstruksi Bangunan Di Kelas X Program Keahlian Teknik Gambar Bangunan SMK Negeri 1 Stabat. Jurnal Education Building, 2(1).

Mustika, H, dkk. (2017). Penerapan Model Pembelajaran Probing Promting Terhadap Kemampuan Pemecahan Masalah Matematika Siswa. MES Jurnal of Mathematic Education and Science, 2(2).

Purwanto. (2014). Evaluasi Hasil Belajar. Yogyakarta: Pustaka Pelajar.

Putra, I, et al. (2016). Pengaruh Probing Prompting Terhadap Hasil Belajar IPS Dengan Kovariabel Motivasi Berprestasi Pada Siswa Kelas IV. Jurnal PGSD Universitas Pendidikan Ganesha, 4(1).

Safitri, A, et. al. (2015). Penerapan Probing Prompting Untuk Meningkatkan Berpikir Kritis Siswa Pada Pembelajaran IPS Di SD. Jurnal PGSD Kampus Cibiru, 3(2).

Susanti, E. (2017). Penerapan Model Pembelajaran Probing Promting Untuk Meningkatkan Kemampuan Berpikir Kritis Matematis Siswa Kelas XI IPA 1 Kota Bengkulu. Jurnal Pendidikan Matematika Raflesia, 2(1). 